IZA DP No. 5572

The Impact of Education on Unemployment Incidence and Re-employment Success:

Evidence from the U.S. Labour Market

W. Craig Riddell

Xueda Song

March 2011 


\title{
The Impact of Education on Unemployment Incidence and Re-employment Success: Evidence from the U.S. Labour Market
}

\author{
W. Craig Riddell \\ University of British Columbia \\ and IZA
}

Xueda Song

York University

\section{Discussion Paper No. 5572 \\ March 2011}

IZA

P.O. Box 7240

53072 Bonn

Germany

Phone: +49-228-3894-0

Fax: +49-228-3894-180

E-mail: iza@iza.org

Any opinions expressed here are those of the author(s) and not those of IZA. Research published in this series may include views on policy, but the institute itself takes no institutional policy positions.

The Institute for the Study of Labor (IZA) in Bonn is a local and virtual international research center and a place of communication between science, politics and business. IZA is an independent nonprofit organization supported by Deutsche Post Foundation. The center is associated with the University of Bonn and offers a stimulating research environment through its international network, workshops and conferences, data service, project support, research visits and doctoral program. IZA engages in (i) original and internationally competitive research in all fields of labor economics, (ii) development of policy concepts, and (iii) dissemination of research results and concepts to the interested public.

IZA Discussion Papers often represent preliminary work and are circulated to encourage discussion. Citation of such a paper should account for its provisional character. A revised version may be available directly from the author. 
IZA Discussion Paper No. 5572

March 2011

\begin{abstract}
The Impact of Education on Unemployment Incidence and Re-employment Success: Evidence from the U.S. Labour Market ${ }^{*}$

This study investigates the causal effects of education on individuals' transitions between employment and unemployment, with particular focus on the extent to which education improves re-employment outcomes among unemployed workers. Given that positive correlations between education and labour force transitions are likely to be confounded by the endogeneity of education, we make use of data on compulsory schooling laws and child labour laws as well as conscription risk in the Vietnam War period to create instrumental variables to identify the causal relationships. Results indicate that education significantly increases re-employment rates of the unemployed. Particularly large impacts are found in the neighborhoods of 12 and 16 years of schooling. Evidence on the impact of formal schooling on unemployment incidence is mixed.
\end{abstract}

JEL Classification: $\quad$ I20, J64

Keywords: education, labour market transitions, unemployment, causal effects, compulsory schooling laws, child labour laws, Vietnam War draft

Corresponding author:

W. Craig Riddell

Department of Economics

University of British Columbia

997-1873 East Mall

Vancouver, BC V6T 1 Z1

Canada

E-mail: criddell@interchange.ubc.ca

\footnotetext{
"We thank David Card, Daniel Parent, Ben Sand, Arthur Sweetman, two anonymous referees and the editors for their useful comments and suggestions and Thomas Lemieux for providing data on cohortlevel conscription risk during the Vietnam War era.
} 


\section{Introduction}

Rapid change is a characteristic feature of the labour market. About one-half of all new worker-employer matches end within the first year and about one-fifth of all workers have been with their employer for less than one year (Farber, 1999). Gross flows are huge in comparison with net changes in stocks. Each year, roughly $10 \%$ of all jobs are destroyed, and another one in ten is newly created (Davis and Haltiwanger, 1999). Structural changes due to technological change, globalization, and the shifting economic environment have focused attention on the ability of individuals, regions and countries to adapt to changing circumstances. In this study we examine the role played by education in labour market adjustment to change.

Previous research has shown that education has substantial impacts on labour market outcomes such as earnings and employment as well as non-market outcomes such as health, longevity, civic participation and criminal activity (Card, 2001; Grossman, 2005; Oreopoulos and Salvanes, 2009). The primary purpose of this study is to investigate the causal effects of education on transitions between labour force states, especially unemployment and employment. The issue that motivates our study is whether additional education improves the ability of the labour force to adjust to economic shocks.

The view that education enhances adaptability to change has a long history. Early contributors to human capital theory regarded schooling (and experience) as mechanisms that would enhance individuals' ability to make efficient decisions in the face of changing circumstances. Schultz (1975) surveys this literature - much of it based on studies of the agricultural sector - and concludes that additional education and experience lead to more efficient decision making by consumers, households and workers, and in particular to more rapid adjustment to changes in economic opportunities. Drawing on sociological and psychological literature, Fullan and Loubser (1972) identify various dimensions of adaptive skills, and analyze qualitatively the relationship between education and major dimensions of adaptive capacity: the capacity for variation (the ability to generate new ideas and alternative solutions to problems) and the capacity for selective retention (the ability to evaluate and consequently select and apply new ideas to the solution of problems). Studies such as Globerman (1986) and Bartel and Litchenberg 
(1987) conclude that better educated workers have a comparative advantage with respect to adjustment to and implementation of new technology.

Our investigation builds on this theme that formal schooling may enhance individuals' ability to adapt to changing circumstances. The research question of primary interest is whether education improves re-employment outcomes among unemployed job seekers. We also examine whether education reduces the likelihood of becoming unemployed.

Several previous studies report associations between education and the incidence and duration of unemployment. Farber (2004) finds that job losers with higher levels of education have higher post-displacement employment rates and are more likely to be reemployed full-time. Using UK data, Nickell (1979) analyzes the relationship between education and the incidence and duration of unemployment. He concludes that each year of schooling up to 12 years reduces the expected duration of unemployment by over 4 percent, and that the acquisition of qualifications at ordinary levels or above reduces the expected unemployment duration by 12 percent. Mincer (1991) similarly demonstrates shorter duration of unemployment for better educated workers.

The correlations between education and unemployment incidence and duration found in these studies, however, are likely to be confounded by the endogeneity of education, and do not necessarily represent the causal effect of education. Positive associations between education and re-employment rates of unemployed workers could arise because of unobserved factors that are correlated with both variables. For example, individuals from advantaged backgrounds with well-connected social networks may enjoy better employment opportunities and may also acquire more schooling. Similarly, those with greater innate ability or motivation may acquire additional education and respond more effectively to job loss. Positive correlations between the probability of reemployment and education based on ordinary least squares (OLS) estimates may overestimate the effects of education on re-employment and fail to accurately portray the causal link between the two. ${ }^{1}$

\footnotetext{
${ }^{1}$ Griliches (1977) and Card (2001) discuss the endogeneity of education and the potential biases of OLS estimates in the context of estimating the impacts of schooling on earnings.
} 
To address the endogeneity of education we make use of compulsory schooling laws and child labour laws as well as conscription risk in the Vietnam War period to create instrumental variables to identify the causal relationships between education and unemployment and re-employment outcomes. An important feature of our IV strategy is that of obtaining estimated impacts of additional schooling at both the secondary and post-secondary levels. Relying on longitudinal data constructed from the 1980-2005 Current Population Survey (CPS) and the 1980 Census, we study the impacts of education on the probability of becoming unemployed and on the probability of reemployment at the survey date conditional on being unemployed in a previous period. Our results indicate that education significantly increases re-employment success among the unemployed. We also find evidence that additional post-secondary education reduces unemployment incidence, but additional secondary schooling does not reduce the probability of becoming unemployed.

Based on CPS data, for example, our IV estimates imply that the probability of reemployment conditional on being unemployed one year earlier is about 40 percentage points higher for high-school graduates than for those who did not complete high school, with each additional year of schooling leading to a 4.7-percentage-point increase in the probability of re-employment. Based on 1980 Census data, graduating from college increases the probability of full-time re-employment by over 40 percentage points for those unemployed for more than 8 weeks in the previous year. An additional year of schooling increases the probability of full-time re-employment by 6 to 7 percentage points. Given the general consistency in findings across different data sets and alternative instruments for schooling (that influence attainment at different levels of education), our results provide empirical support for the hypothesis that there exists a causal link between education and transitions from unemployment to employment.

We also find evidence of heterogeneous impacts of education on adjustment to job loss. The impacts of additional schooling on re-employment rates are particularly large in the ranges of 11-13 and 15-16 years of schooling. Beyond 16 years of schooling there is evidence of diminishing returns. Below-average impacts are also evident for years of education less than 11 years. 
To our knowledge, our study is the first to establish a causal link between education and transitions between employment and unemployment. It also contributes to the literature on the private and social benefits of education. To the extent that education reduces unemployment incidence and/or improves re-employment outcomes among the unemployed, the private and social benefits of education may be understated by standard outcome measures. Further, this study has implications for public policy. It provides empirical evidence that supports education as a means to enhance the capacity of the work force to adjust to economic shocks, a valuable attribute in a dynamic labour market. It also lends support to the case for education as a "preventative" alternative to government-sponsored adjustment assistance policies, which are often based on a "repair shop" model that deals with problems ex post.

The paper is organized as follows. Section 2 outlines our empirical framework and describes the data. The empirical results on the effects of education on individuals' adaptability to employment shocks are reported and discussed in Section 3. We discuss the implications of the differences between the OLS and IV estimates in Section 4 and conclude in Section 5.

\section{Empirical Framework and Data}

Our primary interest lies in whether formal education improves re-employment outcomes of unemployed job seekers, i.e., influences Prob $\left(E_{t} \mid U_{t-1}\right)$. However, a potentially important issue that arises in analyzing the factors that influence the re-employment rate is that the sample consists only of the unemployed, which may result in sample selection bias. ${ }^{2}$ More education may affect the chances of becoming unemployed, and therefore the characteristics of individuals in the sample. For example, the more highly educated may be disproportionately voluntarily unemployed, or previously employed in sectors with higher job mobility. We therefore consider a more general model that examines the factors that influence both Prob (U) and Prob (E | U). In this framework, the sample selection issue is addressed in several ways. First, we apply our IV strategy to estimating

\footnotetext{
${ }^{2}$ It is worth noting that the vast literature on the impacts of education on earnings faces a similar problem of potential selection bias -- the sample consists only of those employed. If schooling influences labour force participation or the probability of being employed conditional on participation, estimated returns to education are potentially subject to selection bias.
} 
the effect of schooling on transitions into unemployment from employment and out-ofthe-labour force. The impact of schooling on the incidence of unemployment is of interest in its own right, and also provides information on the potential importance of selection bias in analyzing re-employment success among unemployed workers. Second, in order to address concerns that more educated workers may be more likely to experience voluntary unemployment, we examine re-employment success excluding job leavers from the sample. In addition, we also obtain results on job losers, thus excluding those who enter unemployment from non-participation (new entrants and re-entrants). Third, we also adopt a control function approach to addressing potential selection bias.

Measuring transitions between unemployment and employment requires longitudinal data. We use two data sources that have a quasi-longitudinal structure: the Current Population Survey (1980-2005) and the 1980 Census. Details on these data sources, our measures of labour force transitions, and sample selection are provided in the following sub-sections. We also explain the creation of instrumental variables for schooling based on compulsory schooling laws, child labour laws, and conscription risk during the Vietnam War period.

\subsection{Current Population Survey}

The CPS rotation group structure keeps an individual in the sample for four consecutive months, out of the sample for eight months, then in again for another four months before she leaves the sample permanently. We make use of this longitudinal component to match individuals across two years, employing a matching procedure similar to the one developed by Madrian and Lefgren (1999). ${ }^{3}$ As noted previously, our principal focus is on the probability of re-employment conditional on being unemployed one year earlier. We also analyze transitions into unemployment.

Educational attainment is a key variable in the empirical analysis. In 1992, the CPS question on educational attainment changed its emphasis from years of education to degree receipt. We follow Jaeger (1997) and create measures of "years of schooling” and "high-school graduation" that are consistent before and after 1992. Because data on high-

\footnotetext{
${ }^{3}$ Prior to 1980 , several changes and omissions in the variables that identify households and individuals make matching individuals from two consecutive years difficult to impossible. In addition, because of changes in the CPS household identifiers in the mid-1980s and mid-1990s, data from 1985 and 1995 can't be matched to data for the subsequent year.
} 
school diploma receipt were not available before 1992, "high-school graduation” is defined as the completion of 12 years of schooling.

The sample is restricted to wage and salary workers aged between 20 and 65, who work in the private sector or the government. We exclude full-time students, respondents who were self-employed or worked without pay, and observations with missing variables. Immigrants are also excluded in order to focus on those whose educational attainment was potentially influenced by U.S. child labour and compulsory schooling laws. For the empirical analysis focusing on transitions from unemployment to employment, we further restrict the sample to those who were unemployed in the previous year. The final sample size of unemployed workers is 86,329 after we merge the CPS data with data on compulsory schooling laws and child labour laws over the period 1914-1978. As shown by the summary statistics in Table 1,53\% of those unemployed in the previous year became re-employed one year later. The average number of years of schooling completed by respondents is 12.2, and 76\% had graduated from high school. Excluding job leavers results in a sample with slightly lower educational attainment and a re-employment rate of $52 \%{ }^{4}$

\subsection{Census}

The 1980 Census provides information about each respondent's current labour market status as of the reference week, as well as information about labour market activities in the previous year. In particular, it provides information on the number of weeks spent unemployed and the number of weeks spent working in the last calendar year for each respondent. ${ }^{5}$ Based on the Census data, we measure re-employment outcomes as the probability of being employed on a full-time basis at the time of the survey conditional on being unemployed for more than eight weeks in the previous year. ${ }^{6}$

For the analysis of 1980 Census data using compulsory schooling laws and child labour laws as IV for schooling, we restrict the sample to those aged 20-65 at the survey date and born in the U.S. We exclude students, respondents who lived in group quarters,

\footnotetext{
${ }^{4}$ We constructed a consistent series on job leavers using the variables "whylk" over the period 1980-93 and "untype" over the period 1989-2005.

${ }^{5}$ The 1980 Census was chosen because of the availability of information on weeks of unemployment, information that was not provided in other Censuses.

${ }^{6}$ We chose unemployment in excess of eight weeks in order to focus on those who experienced a behaviorally significant spell of unemployment. Other choices such as 6, 10, 12 and 20 weeks yielded very similar results, as did including those re-employed on a part-time basis.
} 
and those who worked without pay. In order to focus on individuals with relatively strong attachment to the labour force, we further restrict the sample to those who worked at some point during the previous year. ${ }^{7}$ The final sample size is 307,171 after we merge the census data with data on compulsory schooling laws and child labour laws over the period 1914-1978. As shown in Table 2, 45\% of those unemployed for more than 8 weeks in the previous year became re-employed full-time one year later. Educational attainment in the 1980 Census is somewhat lower than in the CPS data, reflecting the rise in education over the period 1980-2005.

For the analyses of 1980 Census data using conscription risk in the Vietnam War period as IV for schooling, we restrict the sample to males of "the Vietnam generation," i.e., males born between 1935 and 1959. We exclude students, respondents who lived in group quarters, those not born in U.S. and those who worked without pay. In order to focus on individuals with relatively strong attachment to the labour force, we further restrict the sample to those who ever worked in the previous year. The final sample size is 130,739 after we merge the census data with data on conscription risk in the Vietnam War. As shown in Table 2, 50\% of those unemployed for more than 8 weeks in the previous year became re-employed by the survey date. According to the 1980 Census, $29 \%$ of American men had attended college although only 12\% reported having graduated from college.

\subsection{Compulsory Schooling Laws and Child Labour Laws}

We use compulsory schooling laws and child labour laws to obtain instrumental variable estimates of the causal effects of education on unemployment incidence and the probability of re-employment. Identification of the IV estimates comes from changes over time in the number of years of compulsory education or the earliest grade at which children are allowed to work in a given state. The identifying assumption is that conditional on state of birth, cohort of birth, and survey year, the timing of the changes in compulsory attendance laws and child labour laws within each state is uncorrelated with other policy changes and individual characteristics that also influence the probability of re-employment.

\footnotetext{
${ }^{7}$ We also analyzed a somewhat larger sample that included those unemployed but not employed during the previous year. The results were very similar.
} 
Changes in compulsory schooling laws and child labour laws have been shown to have significant effects on educational attainment, and have been a commonly-used instrument for education. Examples include Acemoglu and Angrist's (2000) study of social returns to education, Lochner and Moretti's (2004) study on crime, LlerasMuney's (2005) study on adult mortality, Milligan, Moretti and Oreopoulos (2004) analysis of civic participation, and Oreopoulos (2006) study of the impacts of law changes that affected a large proportion of the population in the UK and Ireland.

Years of compulsory attendance is defined as the higher value of: (i) the minimum number of years that a child is required to stay in school, and (ii) the difference between the oldest age by which he is required to enroll in school and the youngest age at which he is allowed to leave school. Child labour laws are defined as the earliest grade in which children are allowed to leave school to enter the labour market. For compulsory attendance laws, we create four indicator variables to indicate whether the number of years of compulsory attendance is 8 or less, 9,10 , or 11 or more. For child labour laws, we create four indicator variables to indicate whether the minimum number of years of schooling before work is permitted is 6 or less, 7,8 , or 9 or more. In the time period relevant for our sample, 1914-1978, most states changed compulsory attendance levels and child labour laws several times, and not always upward.

The linkage between the 1980 census data and data on compulsory schooling laws and child labour laws is established based on the birthplace of each individual and the year when the individual turned 14. Schmidt (1996) finds that the effects of compulsory schooling laws in the U.S. were largest when matched to individuals at age 14. Acemoglu and Angrist (2000), Lleras-Muney (2002), Schmidt (1996), and Goldin and Katz (2003) adopt the same procedure in their studies based on U.S. data. Because the CPS does not report the birthplace of the respondents or the state of residence when the respondents turned 14, we link the CPS data with data on compulsory schooling laws and child labour laws based on the state of residence at the time of the survey. Although this introduces some measurement error into our instrumental variables, previous studies suggest that such measurement error is not likely to seriously affect the instrumental variable estimates (Milligan, Moretti and Oreopoulos, 2004). 
Are compulsory attendance laws a valid instrument in our setting? To a considerable extent, this question has been addressed in previous studies. One potential concern is that changes in attendance laws may simply reflect underlying trends in educational attainment, as could arise if states that anticipate more rapid increases in schooling are more likely to adopt more stringent attendance requirements. This issue has been extensively examined by Lleras-Muney (2002) and Lochner and Moretti (2004), who conclude that revisions to compulsory attendance laws alter educational attainment rather than vice versa. Another potential concern is that changes in schooling laws may be correlated with other policy changes (such as those to state UI systems) that might alter re-employment rates among the unemployed. However, this is unlikely to be the case for several reasons. First, any such policy changes would need to have differential effects by educational attainment, which seems improbable. Second, and perhaps most important, even contemporaneous correlations between changes in state schooling laws and policies that influence the unemployed do not affect the validity of our instruments because the compulsory attendance laws influenced schooling outcomes many years prior to the occurrence of the employment and unemployment spells that we analyze. As noted, the schooling laws that influenced educational outcomes in our sample were those in place during the period 1914-1978, and we link those to the individual's state of school attendance at age 14. The employment and unemployment spells occurred during the period 1980-2005, and are restricted to individuals aged 20 to 65 during that time period.

\subsection{Conscription Risk in the Vietnam War Era}

Because the instruments based on compulsory schooling laws and child labour laws are limited in the range of schooling years affected, the IV estimates yield insights into the impact of high-school education on labour market transitions. In order to identify the causal effects of college education on unemployment incidence and the probability of reemployment we use conscription risk in the Vietnam War period to instrument schooling. Throughout most of the Vietnam War, males could enroll in college to obtain deferments that delayed their eligibility for conscription into the Armed Services. Card and Lemieux (2001) find evidence that conscription risk varied significantly across birth year cohorts, due to differences in military manpower requirements and cohort size. By comparing college attainment of males with that of females from the same cohort, they find that draft 
avoidance behavior led to significant increases in both college attendance and college graduation for Vietnam generation males. The measure of conscription risk is calculated as the average number of inductions over the years a cohort was aged 19 to 22 divided by cohort size. ${ }^{8}$ Mean conscription risk over the period is 0.029 with a standard deviation of 0.034 (see Table 2). The rationale for this conscription risk instrument is discussed more fully below.

\section{Education, Unemployment Incidence and Re-employment Outcomes}

This section presents empirical evidence on the causal effects of education on transitions into and out of unemployment. Given that our aim is to determine whether education has any causal role in the post-unemployment adjustment process rather than to determine the magnitude of its effect relative to the effects of other factors, we restrict our analysis to a simple, reduced form specification without developing a structural model of the reemployment process.

\subsection{Results from the Current Population Survey}

We begin by using OLS to assess the impact of education on the probability of reemployment as of the survey date conditional on being unemployed one year earlier. We use those with eight years of schooling or less as the base category and regress the probability of re-employment on a complete set of years of schooling dummies. The regression also controls for survey year, survey month, state of residence, age, gender, race, marital status, and metropolitan status.

Based on the coefficient estimates, Figure 1 displays the relationship between years of schooling and the probability of re-employment, controlling for other influences on re-employment rates. It shows an increase in the probability of re-employment from about 0.52 at low levels of schooling to 0.70 at high education levels. The increase in the re-employment probability is particularly pronounced as schooling increases from 11 to 13 years and from 15 to 16 years. Ideally, we would like to estimate a general model where the effect of education on the probability of re-employment varies across years of schooling. This, however, is not empirically feasible because the instruments we use are

\footnotetext{
${ }^{8}$ Malamud and Wozniak (2008) also use this measure of conscription risk to analyze the effects of college education on geographic mobility.
} 
limited in the range of schooling years affected and in the amount of actual variation. Our analyses using compulsory schooling laws and child labour laws as IVs, therefore, are based on models where the main independent variable is either years of schooling or a dummy for high-school graduation.

The OLS estimates of the effects of high-school graduation and years of schooling on the probability of re-employment are presented in the first column of Tables 3 and 4 respectively. The estimate in Table 3 suggests that graduating from high school is associated with an 11.7-percentage-point increase in the probability of re-employment given being unemployed one year before. An additional year of schooling is associated with a 2-percentage-point increase in this probability. Estimation results not reported here also indicate that whites, males, married people, and individuals living in large metropolitan areas enjoy an advantage over others in locating a new job.

The OLS estimates presented above are consistent with the hypothesis that education increases the probability of re-employment after being unemployed. These estimates, however, may reflect the effects of unobserved individual characteristics that influence both the probability of re-employment and schooling choices. To address the endogeneity of education, we use changes in compulsory schooling laws and child labour laws over time to instrument for schooling. Tables 3 and 4 present the 2SLS estimates of the impact of education on the probability of re-employment using specifications identical to those used to obtain the OLS estimates. Results in Column (2) employ both sets of instruments and those in column (3) use only child labour laws.

The first-stage results indicate that, in general, the more stringent the compulsory schooling and child labour legislation, the higher the probability of high-school graduation and the more years of schooling completed. For example, Columns (2) and (3) of Table 3 indicate that individuals who lived in states requiring 9 or more years of schooling before being eligible for work when they were age 14 were 6.8 percentage points more likely to have completed high school compared with individuals who lived in states requiring 6 years or less of schooling when they were age 14 (the excluded category).

To assess the strength of the instrumental variables, we report F-tests for exclusion of instruments in the first-stage regression. As shown in Column (3) in the 
upper panels of Tables 3 and 4, when the three indicator variables derived from child labour laws are used as instruments for schooling, the F-statistic is 10.9 with high-school graduation as the endogenous variable and 13.6 with years of schooling as the endogenous variable, which suggests strong correlations between the instruments and schooling. Both test statistics are above the critical values for weak instruments recommended by Stock, Wright and Yogo (2002). When the three indicator variables derived from compulsory schooling laws are also included as instruments for schooling, however, the F-statistics decline to 6.4 with high-school graduation as the endogenous variable and 8.1 with years of schooling as the endogenous variable. Therefore, we cannot exclude the possibility that instruments based on compulsory schooling laws might be only weakly correlated with schooling. Previous studies, such as Acemoglu and Angrist (2000), Goldin and Katz (2003), and Lleras-Muney (2002), also report that working permit restrictions (child labour laws) are often more binding than school leaving age restrictions.

The bottom panels of Tables 3 and 4 report instrumental variable estimates of the effects of high-school graduation and years of schooling respectively on the probability of re-employment conditional on being unemployed one year earlier. The IV coefficients range between 0.40 and 0.44 for high-school graduation and 0.05 to 0.06 for years of schooling, and are all statistically significant. Given the strength of the first-stage relationships, we have more confidence in the IV estimates based on child labour laws. These imply that graduating from high school increases the probability of re-employment by 44 percentage points and that an additional year of schooling increases the reemployment rate by 5.4 percentage points. Both estimated impacts are economically large relative to the mean re-employment rate of 0.53 as well as statistically significant. Irrespective of the instruments used, the IV point estimates are consistently higher than their OLS counterparts. We discuss the differences between the OLS and IV estimates later in the paper.

One potential concern with these results is that more educated workers may be more likely to voluntarily leave their jobs, and may also transit quickly to a new job. Columns (4) to (6) in Tables 3 and 4 report results that exclude from the sample those who entered unemployment by quitting their previous job. The estimated impact of high- 
school completion on re-employment success declines a small amount (less than 10\%) according to both the OLS and IV estimates. A small decline is also evident in the coefficient on years of schooling estimated by IV. Overall, however, the estimated impacts of education on re-employment remain large and statistically significant.

We also excluded from the sample new entrants and re-entrants, thus focusing the estimation exclusively on job losers. The sample of job losers is considerably smaller $(36,191)$ and the IV estimates are less precise than those in Tables 3 and $4 .{ }^{9}$ Nonetheless, the results are similar to those for the full sample. The OLS and IV estimates are all statistically significant at the 1\% level; the OLS estimates are almost identical to those reported in Tables 3 and 4, while the IV estimates (and their standard errors) are considerably larger than their counterparts in Tables 3 and 4.

As discussed previously, we also analyze flows into unemployment from employment and non-participation. The impact of education on these transitions is of interest in its own right, but also yields insights into the nature of selection into the unemployed pool. Figure 2 shows the partial relationship between the probability of job loss, prob $\left(\mathrm{U}_{\mathrm{t}} \mid \mathrm{E}_{\mathrm{t}-1}\right)$, and years of schooling. There is a negative, but quantitatively modest in size, partial relationship between schooling and the likelihood of job loss (which declines from about 0.06 for those with 9-11 years of schooling to 0.03 for those with 16-18 years). The largest decline occurs between 11 and 12 years of completed schooling, suggesting that high-school completion may be an important predictor of job loss. Although not shown for space reasons, there is no evidence of a partial relationship between education and the likelihood on entering unemployment from out-of-the-labour force.

Table 5 reports the results of the regression analysis of transitions into unemployment from employment. The OLS estimates suggest a weak negative relationship between education and the likelihood of job loss, as indicated in Figure 2. However, the IV estimates - both those for high-school completion and years of schooling - are positive in sign and are not statistically different from zero. Note that the first-stage relationship - especially that based on child labour laws as IVs - is strong. We conclude that formal schooling may reduce the probability of job loss for the sample as a

\footnotetext{
${ }^{9}$ These are not shown in order to conserve space, but are available on request.
} 
whole; the estimated average treatment effect is negative and statistically significant. However, for the subset of individuals whose educational attainment was altered by child labour laws there is no evidence of a negative relationship between schooling and the likelihood of job loss - the local average treatment effect (LATE) is not significantly different from zero. Although not shown, we also find the same result when we analyze transitions into unemployment from non-participation. ${ }^{10}$

These results suggest that additional formal education at the secondary school level does not influence the incidence of unemployment. Thus there is no evidence of selection into unemployment on the basis of educational attainment, at least for the individuals in our sample whose schooling was affected by child labour laws.

As a further check on the possibility of selection bias we estimated a standard selection bias correction model, using as exclusion restrictions in the first stage Probit model higher order terms (interactions between covariates such as gender, race, age, etc.). The results are reported in Appendix Table A1. Again the OLS estimates suggest the presence of selection bias. The coefficient on the Inverse Mills Ratio (IMR) term is positive and statistically significant and the estimated impact of education declines substantially relative to the OLS estimates in Tables 3 and 4 that do not control for selection. However, once we instrument for education there is no evidence of selection bias. The IMR terms are not significantly different from zero, and the IV estimates are very similar to those in Tables 3 and 4 .

In summary, our IV estimates indicate that additional schooling at the secondary school level does exert a causal influence on the re-employment outcomes of the unemployed. The magnitudes of the estimated impacts are large. Based on the sample that excludes job leavers, high-school completion raises the probability of re-employment within the next 12 months by about 0.40 and each year of additional schooling increases the re-employment rate by about 0.05 . These estimated LATEs do not appear to be affected by sample selection. These results suggest that the subset of the sample that altered their formal schooling as a consequence of child labour laws is not affected by sample selection into the unemployed pool.

\footnotetext{
${ }^{10}$ In this case neither the OLS nor IV estimates of the impact of education are statistically significant.
} 


\subsection{Results from the 1980 Census}

We now turn to an alternative data source, the 1980 Census. The census sample size is several times larger than that for the CPS, and thus may yield more precise estimates. In addition, because the census was collected at the beginning of our CPS sample period, a larger proportion of respondents were probably influenced by compulsory schooling laws, which were more binding early in the $20^{\text {th }}$ century. Similar to Figure 1, Figure 3 plots the relationship between years of schooling and the regression-controlled probability of full-time re-employment conditional on being unemployed for more than 8 weeks in the previous year. The figure shows the coefficient estimates of the complete set of schooling dummies after controlling for state of birth, state of residence, gender, race, and cohort of birth (1916-1925, 1936-1945, etc.). As with CPS data, we use those with eight years of schooling or less as the base category. There is a steady increase in the probability of re-employment associated with an increase in years of schooling, with a sharper increase at the high-school graduation stage and the college graduation stage than at other stages of schooling progression. Results based on the 1980 Census data merged with conscription risk in the Vietnam War show very similar patterns as in Figure 3 and are thus not reported here.

The first and fourth columns in Table 6 report OLS estimates of the effects of high-school graduation and years of schooling respectively on the probability of full-time re-employment conditional on being unemployed for more than 8 weeks in the previous year. The estimates indicate that graduating from high school is associated with an 11percentage-point increase in the probability of re-employment, while an additional year of schooling tends to increase the re-employment rate by more than 2 percentage points. These OLS estimates are similar in magnitude to those obtained with CPS data. Estimation results not reported here also indicate that whites, males, and young people enjoy an advantage in locating a new job after being unemployed.

Instrumental variable estimation results based on the sample unemployed for more than eight weeks in the previous year are reported in the remaining columns. As was the case with the CPS data, we focus on the effects of high-school graduation and years of schooling on re-employment success and employ instruments derived from compulsory schooling laws as well as both child labour laws and compulsory schooling 
laws. All F-statistics for exclusion of instruments in the first-stage regressions are above critical values for weak instruments. There is a strong correlation between schooling and both the child labour law and compulsory schooling law instruments, but when both are included the compulsory schooling laws dominate.

The IV coefficients on high-school graduation range between 0.21 and 0.26 in analyses of the probability of re-employment conditional on being unemployed for more than 8 weeks in the previous year. The IV coefficients on years of schooling range between 0.03 and 0.04 in analysis of the probability of re-employment conditional on being unemployed for more than 8 weeks in the previous year. All IV estimates are statistically significant at the $5 \%$ level or better. These estimates indicate that graduating from high school increases the probability of re-employment by over 20 percentage points and an additional year of schooling increases the probability of re-employment by 3 to 4 percentage points. Relative to the mean re-employment rate of 0.45 , these estimated impacts represent increases of $40-50 \%$ and $5-10 \%$ respectively.

We also examine the impact of schooling on the incidence of unemployment using Census data. The analysis focuses on transitions from employment to unemployment, defining individuals as employed in the initial period (the year prior to the survey) those who worked in 1979 and experienced zero weeks of unemployment. As a robustness check we also used a more restrictive definition of employment - those who worked at least 49 weeks in the previous year and experienced zero weeks of unemployment. The partial relationship between the probability of job loss and years of schooling is similar to that shown in Figure 2. The job loss hazard drops from about 0.03 for those with 9-11 years of schooling to 0.0 for those with at least 16 years. Most of the decline takes place between 11 and 12 years of education. Reflecting this weak negative relationship, the OLS coefficient on schooling is -0.002 . However, once we instrument for schooling there is no evidence that education exerts a causal influence on transitions from employment to unemployment. These results, which are not reported to conserve space, are qualitatively very similar to those in Table 5 .

\subsection{Estimates using Conscription Risk in the Vietnam War Period}

In addition to using compulsory schooling laws and child labour laws as instruments for schooling, we also use conscription risk in the Vietnam War period as instruments. These 
IV estimates are particularly helpful in identifying the causal effects of college education on re-employment success. In this case the identification rests on the assumption that Vietnam era male cohorts were not influenced by unobserved factors that might enhance their ability to adjust to employment shocks. As noted previously, Card and Lemieux (2001) conclude that conscription risk varied considerably across birth cohorts, which produced large variations in male college attendance and completion relative to the path followed by female cohorts. We control for other cohort-specific influences on college participation by using the female cohort-level rates of college attendance or completion as well as age (which acts like a cohort fixed effect in a single cross-section). The identifying assumption is that these cohort-specific controls capture the trends in college participation that would have been observed in the absence of the Vietnam era draft. Note that, as was the case for instrumental variables based on compulsory attendance laws, the validity of the conscription risk instrument is not affected by contemporaneous correlation between unobserved factors affecting educational outcomes of Vietnam era males and unobserved influences on re-employment rates. Our analysis focuses on adjustment to spells of unemployment experienced in 1979, the year prior to the 1980 Census, many years after college attendance decisions were made by men potentially eligible for the Vietnam draft.

Results are reported separately for college attendance (completing 13 to 15 years of schooling), college graduation (completion of 16 or more years of schooling) and years of schooling (see Table 7). In each case the first-stage F statistic indicates a strong correlation between the conscription risk measure and educational attainment beyond high school. The magnitudes of the coefficients on induction risk in the first-stage regression also indicate a strong relationship. According to these estimates a $10 \%$ increase in the risk of being drafted raises college attendance by 10 percentage points and college graduation by 6.5 percentage points. Each of the IV estimates is economically large and statistically significant at the $5 \%$ level. Both college attendance and college completion exert a strong influence on re-employment success according to these estimates. The OLS estimates for years of schooling are a bit larger than their counterparts in Table 6, which are based on a larger sample including both genders. The IV estimate indicates that an additional year of schooling raises the probability of re- 
employment by 6.5 to 7 percentage points, a larger impact than that estimated previously (see Table 6) albeit one that is not significantly different from the earlier estimate.

Each of the IV estimates based on the conscription risk instrument exceeds the corresponding OLS estimate. However, the IV estimates are much less precisely estimated, in part reflecting the smaller sample sizes when we focus on males only, and are not necessarily significantly different than their OLS counterparts.

We also analyzed the relationship between education and transitions from employment to unemployment using Census data matched to conscription risk data. The OLS estimates are very similar to those discussed in the previous section using Census data matched to child labour and compulsory schooling laws. However, in contrast to the results using compulsory schooling and child labour laws as instruments, these IV estimates indicate that education does have an impact on transitions into unemployment (see Table 8). Since the conscription risk instrument affects educational attainment at the college level, this evidence indicates that additional post-secondary education reduces the likelihood of job loss. This finding also suggests that there may be some selection into our unemployed sample at higher levels of education. The IV estimates of the impact of education on the probability of re-employment reported in Table 7 may thus be subject to some selection bias. ${ }^{11}$

\section{$4 \quad$ Why Are IV Estimates Higher than OLS Estimates?}

The empirical results based on both CPS and Census data indicate that the IV estimates are consistently higher than the corresponding OLS estimates, although the difference between the two estimates is not always statistically significant. Thus our results indicate that the causal effect of education on re-employment success is at least as large as - and perhaps larger than - would be suggested by standard OLS estimation. Many recent studies of the causal impact of education on earnings have obtained a similar result (Card, 2001). There are several potential explanations for this result. One is the existence of

\footnotetext{
${ }^{11}$ Results using sample selection bias correction methods similar to those used in Appendix Table A1 suggest that the bias is not large. For example, the Heckit-IV estimate associated with college attendance is -0.198 versus -0.105 in Table 8 and that for college graduation is -0.177 versus -0.110 in Table 8 .
} 
measurement error in educational attainment, which results in downward bias in the OLS estimates (Griliches, 1977; Card, 2001). ${ }^{12}$

An alternative explanation is that, in the presence of heterogeneity across individuals in the impacts of additional education, the OLS and IV estimates measure different treatment effects. OLS applied to a sample representative of the population of interest yields an estimate of the average treatment effect (ATE), which shows the expected benefits of additional education experienced by an individual chosen at random from the population. IV methods, on the other hand, generally estimate the local average treatment effect (LATE) for the subset of the population who are actually affected by the instruments (Imbens and Angrist, 1994).

In IV estimation using compulsory attendance and child labour laws as instruments, for example, the IV estimates indicate the impact of education on reemployment success for the "compliers" - those who acquired more schooling than they otherwise would have chosen to acquire as a consequence of changes in the laws. For this subset of the population, the payoff to incremental investments in education may exceed the average return in the population, as represented by the OLS estimates. This could happen, for example, if the individuals who remained in school longer because of these laws are a subset of the population that faces above-average potential returns from additional schooling. If individuals base their educational choices on the anticipated costs and benefits, this situation could arise because these youths faced above-average costs of additional schooling, perhaps because of an inability to borrow to finance their education, because of a need to work to contribute to family income, or because of a greater dislike of school.

Another possible explanation is that there are substantial non-linearities in the impacts of schooling on re-employment outcomes. As is indicated by Figures 1 and 3 there is evidence of diminishing returns to additional education above 16 years of schooling, as well as relatively modest returns for increases in education from 9 to 11 years. In contrast there appear to be above-average returns to education in the range 1113 and 15-16 years of schooling. The instruments used in this study principally influence

\footnotetext{
${ }^{12}$ If, as is likely, the measurement error in educational attainment is non-classical in nature the OLS estimates and IV estimates may both be inconsistent estimates of the returns to schooling (Kane, Rouse and Staiger, 1999).
} 
educational attainment in the ranges with above-average impacts of additional schooling. In the presence of these heterogeneous impacts we expect the IV/LATE estimates to exceed the OLS/ATE estimates that pertain to the entire range of educational attainment. To illustrate this point, we re-estimated the OLS estimates reported in Tables 4 and 6 using the sub-sample with years of schooling in the range 11-13 years and the OLS estimates in Table 7 using the sub-sample with years of schooling in the range 15-17 years. In both cases the OLS point estimates using these sample subsets are very similar to the IV estimates reported in columns 2 and 3 of Table 4, column 6 in Table 6 and the IV coefficient on years of schooling in Table 7. For example, the OLS estimate using a sample restricted to those with 11-13 years of schooling, is 0.054 , very similar or identical to the IV estimates of 0.055 and 0.054 in columns (2) and (3) of Table 4. Similarly, using Census data and restricting the sample to those with 15-17 years of schooling yields an OLS estimate of 0.062, similar to the IV estimate of 0.066 in Table 7. ${ }^{13}$ Thus it does not appear to be necessary to appeal to arguments that those affected by compulsory attendance laws faced unusually large benefits from additional education relative to others with similar levels of completed schooling. According to this interpretation, any intervention that raised educational attainment in the neighborhood of high school completion or college graduation would yield above-average benefits in the form of raising the probability of re-employment.

The non-linearities in the impacts of education on re-employment are consistent with the presence of "sheepskin effects" associated with completion of a high school diploma (12 years of schooling) and a college degree (16 years of schooling). Sheepskin effects have also been found in the impacts of education on earnings (Jaeger and Page, 1996; Ferrer and Riddell, 2002) and on crime (Lochner and Moretti, 2004).

\section{Conclusions}

In a dynamic labour market, the ability to adjust to employment shocks is important for individuals' labour market success as well as the efficiency of the overall market. Studies of the forces that enhance re-employment outcomes are thus relevant and timely.

\footnotetext{
${ }^{13}$ In his study of compulsory schooling in Great Britain and Ireland, Oreopoulos (2006) also finds that the gap between the OLS and IV estimates can be attributed to non-linearities in the returns to schooling.
} 
Previous studies reported evidence of a positive correlation between re-employment rates and educational attainment among unemployed job seekers, as well as a negative correlation between formal education and the incidence of unemployment. Our study contributes to this line of research by empirically assessing the causal effects of education on re-employment outcomes among the unemployed as well as on the probability of job loss.

Based on data from the CPS and the 1980 Census, we find that education significantly increases re-employment success for unemployed workers. According to our estimates from CPS data, graduating from high school increases the probability of reemployment by around 40 percentage points. An additional year of schooling increases this probability by around 4.7 percentage points. IV estimates based on the Census are somewhat smaller but still large in magnitude and statistically significant.

An important feature of our study is the use of instrumental variables that influence educational attainment at the post-secondary level in addition to those that affect secondary level schooling. These IV estimates also imply that college education has large impacts on individuals' ability to adjust to adverse employment shocks. We also find evidence of non-linearities in the effects of education, with particularly large impacts in the neighborhoods of 12 and 16 years of schooling, consistent with sheepskin effects associated with high school completion and college graduation.

The evidence on the relationship between education and the incidence of unemployment is mixed. Although there is a negative partial correlation between schooling and job loss, we find no evidence of a causal relationship at the secondary schooling level, at least for the subset of our sample that was influenced by compulsory schooling and child labour laws. However, we do find evidence that higher education at the post-secondary level reduces the incidence of unemployment.

Early contributors to human capital theory viewed education as an investment that could enhance individuals' ability to make efficient decisions in the face of changing circumstances. Our instrumental variable estimates support this perspective, and provide clear evidence that the positive associations between educational attainment and reemployment success of the unemployed cannot be easily explained away by unobserved factors that are correlated with both variables. 


\section{References}

Acemoglu, Daron and Joshua Angrist. 2000. "How Large Are Human Capital Externalities? Evidence from Compulsory Schooling Laws.” NBER Macroeconomics Annual 2000: 9-59.

Bartel, Ann P., and Frank R. Lichtenberg. 1987. "The Comparative Advantage of Educated Workers in Implementing New Technology.” The Review of Economics and Statistics 69: 1-11.

Card, David. 2001. "Estimating the Return to Schooling: Progress on Some Persistent Econometric Problems.” Econometrica 69: 1127-1160.

Card, David and Thomas Lemieux. 2001. "Going to College to Avoid the Draft: The Unintended Legacy of the Vietnam War” American Economic Review Papers and Proceedings 91 (May): 97-102.

Davis, Steven J. and John Haltiwanger. 1999. “Gross Job Flows” in Orley Ashenfelter and David Card (eds.) Handbook of Labor Economics vol. 3. New York: Elsevier.

Farber, Henry S. 1999. "Mobility and Stability: The Dynamics of Job Change in Labor Markets” in Orley Ashenfelter and David Card (eds.) Handbook of Labor Economics vol. 3. New York: Elsevier.

Farber, Henry S. 2004. “Job Loss in the United States, 1981 to 2001.” Research in Labor Economics 23: 69-117.

Ferrer, Ana M. and W. Craig Riddell. 2002. "The Role of Credentials in the Canadian Labour Market” Canadian Journal of Economics 35: 879-905.

Fullan, Michael, and Jan J. Loubser. 1972. "Education and Adaptive Capacity.” Sociology of Education 45: 271-287.

Globerman, Steven. 1986. "Formal Education and the Adaptability of Workers and Managers to Technological Change.” p. 41-69 in Adapting to Change: Labour Market Adjustment in Canada, edited by W. Craig Riddell. Toronto: University of Toronto Press.

Goldin, Claudia, and Lawrence F. Katz. 2003. "Mass Secondary Schooling and the State: The Role of State Compulsion in the High School Movement.” NBER Working Paper 10075. 
Griliches, Zvi. 1977. "Estimating the Returns to Schooling: Some Econometric Problems.” Econometrica 45: 1-22

Grossman, Michael. 2005. “Education and Nonmarket Outcomes” NBER Working Paper 11582.

Imbens, Guido, and Joshua Angrist. 1994. "Identification and Estimation of Local Average Treatment Effects.” Econometrica 62: 467-75.

Jaeger, David A. 1997. "Reconciling the Old and New Census Bureau Education Questions: Recommendations for Researchers.” Journal of Business and Economic Statistics 15 (3): 300-309.

Jaeger, David A. and Marianne E. Page. 1996. "Degrees Matter: New Evidence on Sheepskin Effects in the Returns to Education” Review of Economics and Statistics 78: 733-740.

Kane, Thomas J., Cecilia Elena Rouse, and Douglas Staiger. 1999. "Estimating Returns to Schooling when Schooling is Misreported.” NBER Working Paper 7235.

Lleras-Muney, Adrianna. 2002. "Are Compulsory Attendance and Child Labor Laws Effective? An Analysis from 1915 to 1939.” Journal of Law and Economics 45: 401435.

Lleras-Muney, Adriana. 2005. "The Relationship between Education and Adult Mortality in the United States." Review of Economic Studies 72: 189-221.

Lochner, Lance and Enrico Moretti. 2004. "The effect of education on crime: evidence from prison inmates, arrests and self-reports” American Economic Review 94: 155-189.

Madrian, Brigitte, and Lars John Lefgren. 1999. “A Note on Longitudinally Matching Current Population Survey (CPS) Respondents.” NBER Technical Working Paper 247.

Malamud, Ofer and Abigail Wozniak. 2008. "The Impact of College Education on Geographic Mobility: Identifying Education Using Multiple Components of Vietnam Draft Risk” IZA Discussion Paper 3432, April.

Milligan, Kevin, Enrico Moretti and Philip Oreopoulos. 2004. "Does Education Improve Citizenship: Evidence from the U.S. and U.K.” Journal of Public Economics 88 (August): 1667-1695. 
Mincer, Jacob. 1991. “Education and Unemployment.” NBER Working Paper 3838.

Nickell, Stephen. 1979. "Estimating the Probability of Leaving Unemployment." Econometrica 47: 1249-1266.

Oreopoulos, Philip. 2006. "Estimating Average and Local Average Treatment Effects of Education when Compulsory School Laws Really Matter.” American Economic Review 96 (1): 152-175.

Oreopoulos, Philip and Kjell Salvanes. 2009. "How Large are Returns to Schooling? Hint: Money Isn’t Everything” mimeo.

Schmidt, Stefanie. 1996. "School Quality, Compulsory Education Laws, and the Growth of American High School Attendance, 1915-1935.” Ph.D. dissertation, MIT.

Schultz, Theodore. 1975. "The Value of the Ability to Deal with Disequilibria.” Journal of Economic Literature 13 (3): 827-846.

Stock, James H., Jonathan H. Wright and Motohiro Yogo. 2002. “A Survey of Weak Instruments and Weak Identification in Generalized Method of Moments” Journal of Business and Economic Statistics 20 (4): 518-529. 
Figure 1

Regression-adjusted Probability of Re-employment Conditional on Being Unemployed One Year Earlier by Years of Schooling

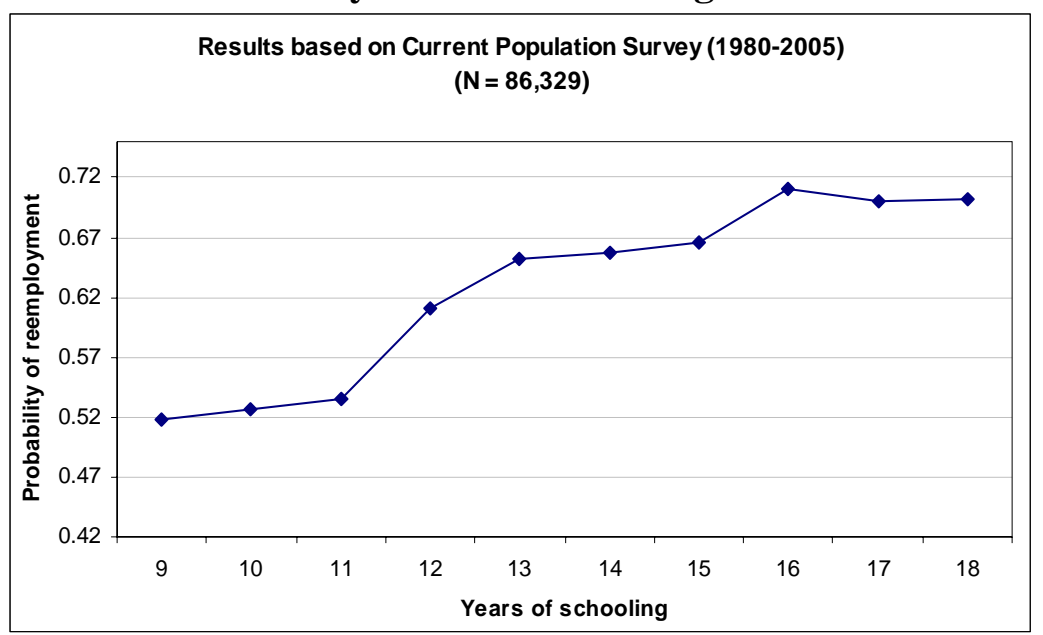

Note: Regression-adjusted probability of re-employment is obtained by conditioning on survey year, survey month, state of residence, age, gender, race, marital status, and metropolitan status. The graph displays the coefficient estimates on the complete set of schooling dummies. The intercept applies to the base category - white males surveyed in January 1980 and 1981 who were 35 to 44 years of age, had eight years of schooling or less, were married, and lived in a non-metropolitan area in California.

\section{Figure 2}

\section{Regression-adjusted Probability of Job Loss by Years of Schooling}

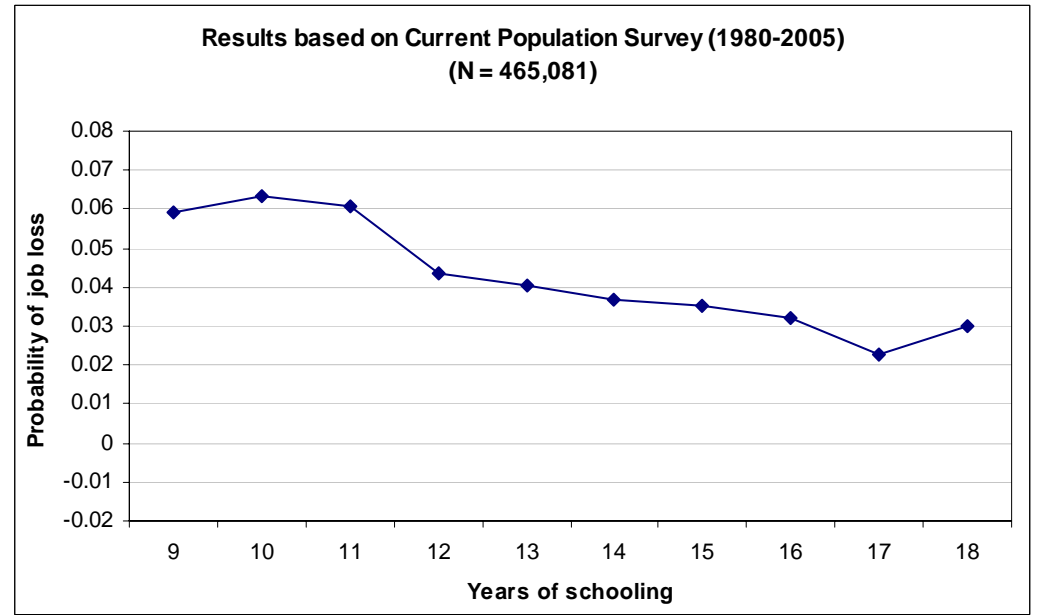

Note: Regression-adjusted probability of job loss is obtained by conditioning on survey year, survey month, state of residence, age groups, gender, race, marital status, and metropolitan status. The graph displays the coefficient estimates on the complete set of schooling dummies. The intercept applies to the base category - white males surveyed in January 1980 and 1981 who were 35 to 44 years of age, had eight years of schooling or less, were married, lived in a non-metropolitan area in California at the time of the survey. 
Figure 3

Regression-adjusted Probability of Full-time Re-employment Conditional on Being Unemployed for more than Eight Weeks in the Previous Year by Years of Schooling

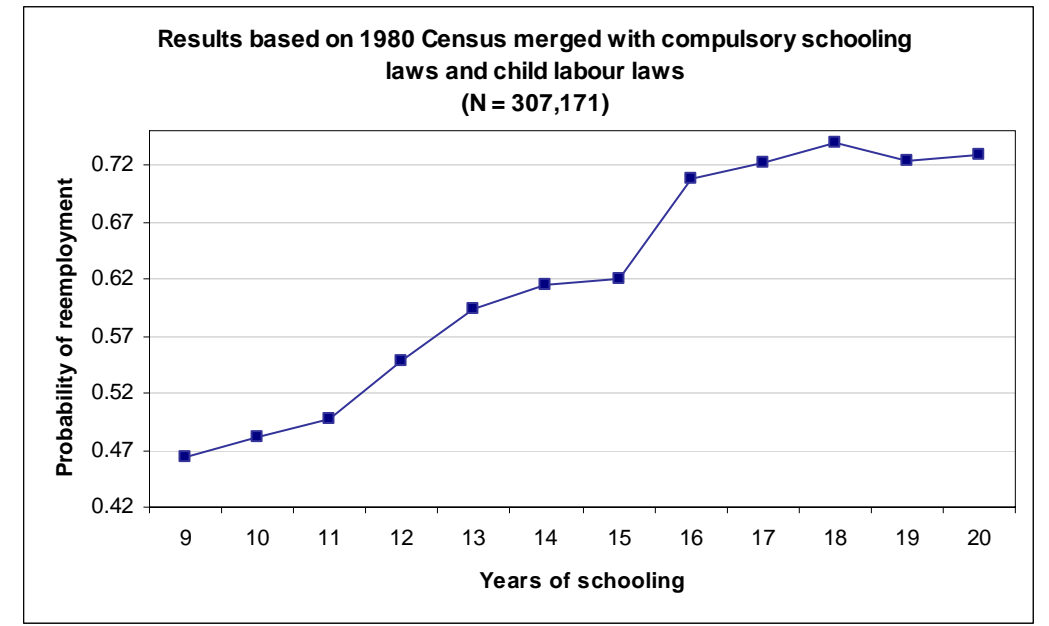

Note: Regression-adjusted probability of full-time re-employment is obtained by conditioning on state of birth, state of residence, gender, race, and cohort of birth (19161925, 1926-1935, etc.). The graph displays the coefficient estimates on the complete set of schooling dummies. The intercept applies to the base category - white males who were born in California between 1936 and 1945, had eight years of schooling or less, and lived in California. 
Table 1

Descriptive Statistics for the Current Population Survey (1980-2005) Sample

\begin{tabular}{|c|c|c|c|c|}
\hline \multirow[b]{2}{*}{ Variable } & \multicolumn{2}{|c|}{$\begin{array}{l}\text { All unemployed } \\
(\mathrm{N}=86,329)\end{array}$} & \multicolumn{2}{|c|}{$\begin{array}{c}\text { Unemployed excluding } \\
\text { job leavers } \\
(\mathrm{N}=76,269)\end{array}$} \\
\hline & Mean & Std. Dev. & Mean & Std. Dev. \\
\hline Being re-employed & 0.531 & 0.499 & 0.522 & 0.500 \\
\hline Years of schooling & 12.158 & 2.798 & 12.090 & 2.818 \\
\hline High-school graduate & 0.763 & 0.425 & 0.756 & 0.430 \\
\hline Age & 40.539 & 11.561 & 40.684 & 11.629 \\
\hline Compulsory schooling $\leq 8$ & 0.178 & 0.383 & 0.179 & 0.384 \\
\hline Compulsory schooling $=9$ & 0.361 & 0.480 & 0.359 & 0.480 \\
\hline Compulsory schooling $=10$ & 0.116 & 0.320 & 0.116 & 0.320 \\
\hline Compulsory schooling $\geq 11$ & 0.345 & 0.475 & 0.347 & 0.476 \\
\hline Child labour $\leq 6$ & 0.043 & 0.202 & 0.043 & 0.202 \\
\hline Child labour = 7 & 0.120 & 0.325 & 0.120 & 0.325 \\
\hline Child labour $=8$ & 0.405 & 0.491 & 0.407 & 0.491 \\
\hline Child labour $\geq 9$ & 0.433 & 0.496 & 0.431 & 0.495 \\
\hline
\end{tabular}

Note: Sampling weights are used in all statistics.

Table 2

\section{Descriptive Statistics for Samples Based on the 1980 Census}

\begin{tabular}{|c|c|c|c|c|}
\hline \multirow[b]{2}{*}{ Variable } & \multicolumn{2}{|c|}{$\begin{array}{l}\text { Base sample merged with } \\
\text { compulsory schooling } \\
\text { laws and child labour laws } \\
(\mathrm{N}=307,171)\end{array}$} & \multicolumn{2}{|c|}{$\begin{array}{c}\text { Base sample merged with } \\
\text { conscription risk in } \\
\text { Vietnam War } \\
(\mathrm{N}=130,739)\end{array}$} \\
\hline & Mean & Std. Dev. & Mean & Std. Dev. \\
\hline Being full-time re-employed & 0.452 & 0.498 & 0.499 & 0.500 \\
\hline Years of schooling & 11.902 & 2.723 & 12.071 & 2.622 \\
\hline High-school graduate & 0.699 & 0.459 & 0.718 & 0.450 \\
\hline College attendance & & & 0.286 & 0.452 \\
\hline College graduate & & & 0.118 & 0.323 \\
\hline Age & 34.364 & 12.224 & 29.414 & 6.665 \\
\hline Compulsory schooling $\leq 8$ & 0.153 & 0.360 & & \\
\hline Compulsory schooling $=9$ & 0.373 & 0.484 & & \\
\hline Compulsory schooling $=10$ & 0.111 & 0.314 & & \\
\hline Compulsory schooling $\geq 11$ & 0.363 & 0.481 & & \\
\hline Child labour $\leq 6$ & 0.064 & 0.245 & & \\
\hline Child labour $=7$ & 0.158 & 0.365 & & \\
\hline Child labour $=8$ & 0.385 & 0.486 & & \\
\hline Child labour $\geq 9$ & 0.393 & 0.488 & & \\
\hline Conscription risk & & & 0.029 & 0.034 \\
\hline
\end{tabular}

Note: The base sample includes all respondents who had been unemployed for more than eight weeks in the previous year. 
Table 3

Estimates of the Effect of High-school Graduation on Probability of Re-employment Conditional on Being Unemployed One Year Earlier

Data source: Current Population Survey (1980-2005)

Instrument for schooling: Compulsory schooling laws and child labour laws

\begin{tabular}{|c|c|c|c|c|c|c|}
\hline & \multicolumn{3}{|c|}{$\begin{array}{c}\text { All unemployed } \\
(\mathrm{N}=86,329) \\
\end{array}$} & \multicolumn{3}{|c|}{$\begin{array}{c}\text { Unemployed excluding job } \\
\text { leavers } \\
(\mathrm{N}=76,269)\end{array}$} \\
\hline & \multirow{2}{*}{$\begin{array}{c}\text { OLS } \\
(1)\end{array}$} & \multicolumn{2}{|c|}{ IV } & \multirow{2}{*}{$\begin{array}{l}\text { OLS } \\
(4)\end{array}$} & \multicolumn{2}{|c|}{ IV } \\
\hline & & $(2)$ & $(3)$ & & $(5)$ & $(6)$ \\
\hline \multicolumn{7}{|c|}{ First stage: dependent variable is high-school graduation } \\
\hline Compulsory schooling =9 & \multicolumn{3}{|c|}{-0.019} & \multicolumn{3}{|c|}{$\begin{array}{l}-0.017 \\
(0.020)\end{array}$} \\
\hline Compulsory schooling $=10$ & \multicolumn{3}{|c|}{$\begin{array}{l}-0.007 \\
(0.021)\end{array}$} & \multicolumn{3}{|c|}{$\begin{array}{l}-0.004 \\
(0.022)\end{array}$} \\
\hline Compulsory schooling $\geq 11$ & \multicolumn{3}{|c|}{0.006} & \multicolumn{3}{|c|}{0.010} \\
\hline Child labour $=7$ & & $\begin{array}{c}0.019 \\
(0.022)\end{array}$ & $\begin{array}{c}0.019 \\
(0.018)\end{array}$ & & $\begin{array}{c}0.019 \\
(0.023)\end{array}$ & $\begin{array}{c}0.021 \\
(0.018)\end{array}$ \\
\hline Child labour $=8$ & & $\begin{array}{c}0.034 \\
(0.025)\end{array}$ & $\begin{array}{c}0.033 \\
(0.019)\end{array}$ & & $\begin{array}{c}0.037 \\
(0.026)\end{array}$ & $\begin{array}{l}0.038^{*} \\
(0.019)\end{array}$ \\
\hline Child labour $\geq 9$ & & $\begin{array}{c}0.068 * * \\
(0.022)\end{array}$ & $\begin{array}{l}0.068 * * \\
(0.018)\end{array}$ & & $\begin{array}{c}0.069 * * \\
(0.023)\end{array}$ & $\begin{array}{c}0.072 * * \\
(0.018)\end{array}$ \\
\hline $\begin{array}{l}\text { F-statistic for exclusion of } \\
\text { instruments }\end{array}$ & & 6.44 & 10.91 & & 6.10 & 10.48 \\
\hline$p$-value & & 0.000 & 0.000 & & 0.000 & 0.000 \\
\hline \multicolumn{7}{|c|}{$\begin{array}{c}\text { Second stage: dependent variable is an indicator variable for being re-employed at the survey } \\
\text { date conditional on being unemployed one year earlier }\end{array}$} \\
\hline High-school graduation & $\begin{array}{c}0.117 * * \\
(0.005)\end{array}$ & $\begin{array}{c}0.398 * \\
(0.156)\end{array}$ & $\begin{array}{c}0.442 * * \\
(0.166)\end{array}$ & $\begin{array}{c}0.113^{* *} \\
(0.005)\end{array}$ & $\begin{array}{c}0.373^{*} \\
(0.156)\end{array}$ & $\begin{array}{c}0.407 * \\
(0.163)\end{array}$ \\
\hline
\end{tabular}

Note: All regressions control for survey year, survey month, state of residence, age groups, gender, race, marital status, and metropolitan status. The robust standard errors corrected for clustering by state of residence and year of birth are in parentheses.

*Significant coefficient at the 5\% level.

**Significant coefficient at the $1 \%$ level. 
Table 4

Estimates of the Effect of Years of Schooling on Probability of Re-employment

Conditional on Being Unemployed One Year Earlier

Data source: Current Population Survey (1980-2005)

Instrument for schooling: Compulsory schooling laws and child labour laws

\begin{tabular}{|c|c|c|c|c|c|c|}
\hline & \multicolumn{3}{|c|}{$\begin{array}{c}\text { All unemployed } \\
(\mathrm{N}=86,329) \\
\end{array}$} & \multicolumn{3}{|c|}{$\begin{array}{c}\text { Unemployed excluding job } \\
\text { leavers } \\
(\mathrm{N}=76,269)\end{array}$} \\
\hline & \multirow{2}{*}{$\begin{array}{c}\text { OLS } \\
(1)\end{array}$} & \multicolumn{2}{|c|}{ IV } & \multirow{2}{*}{$\begin{array}{c}\text { OLS } \\
(4)\end{array}$} & \multicolumn{2}{|c|}{ IV } \\
\hline & & $(2)$ & $(3)$ & & $(5)$ & $(6)$ \\
\hline \multicolumn{7}{|c|}{ First stage: dependent variable is years of schooling } \\
\hline Compulsory schooling =9 & \multicolumn{3}{|c|}{-0.055} & \multicolumn{3}{|c|}{$\begin{array}{l}-0.030 \\
(0.134)\end{array}$} \\
\hline Compulsory schooling $=10$ & \multicolumn{3}{|c|}{$\begin{array}{c}0.023 \\
(0.134)\end{array}$} & \multicolumn{3}{|c|}{0.039} \\
\hline Compulsory schooling $\geq 11$ & \multicolumn{3}{|c|}{$\begin{array}{c}0.001 \\
(0.177)\end{array}$} & \multicolumn{3}{|c|}{$\begin{array}{c}0.048 \\
(0.198)\end{array}$} \\
\hline Child labour $=7$ & & $\begin{array}{c}0.036 \\
(0.153)\end{array}$ & $\begin{array}{c}0.029 \\
(0.117)\end{array}$ & & $\begin{array}{c}0.034 \\
(0.159)\end{array}$ & $\begin{array}{c}0.053 \\
(0.119)\end{array}$ \\
\hline Child labour $=8$ & & $\begin{array}{c}0.114 \\
(0.170)\end{array}$ & $\begin{array}{c}0.105 \\
(0.122)\end{array}$ & & $\begin{array}{c}0.102 \\
(0.178)\end{array}$ & $\begin{array}{l}0.115 \\
(0.122)\end{array}$ \\
\hline Child labour $\geq 9$ & & $\begin{array}{c}0.441^{* *} \\
(0.156)\end{array}$ & $\begin{array}{l}0.431 * * \\
(0.117)\end{array}$ & & $\begin{array}{l}0.436 * * \\
(0.162)\end{array}$ & $\begin{array}{c}0.459 * * \\
(0.121)\end{array}$ \\
\hline $\begin{array}{l}\text { F-statistic for exclusion of } \\
\text { instruments }\end{array}$ & & 8.12 & 13.59 & & 7.51 & 12.67 \\
\hline$p$-value & & 0.000 & 0.000 & & 0.000 & 0.000 \\
\hline \multicolumn{7}{|c|}{$\begin{array}{c}\text { Second stage: dependent variable is an indicator variable for being re-employed at the survey } \\
\text { date conditional on being unemployed one year earlier }\end{array}$} \\
\hline Years of schooling & $\begin{array}{c}0.019 * * \\
(0.001)\end{array}$ & $\begin{array}{l}0.055^{* *} * \\
(0.021)\end{array}$ & $\begin{array}{l}0.054 * * \\
(0.021)\end{array}$ & $\begin{array}{c}0.019 * * \\
(0.001)\end{array}$ & $\begin{array}{l}0.050 * \\
(0.020)\end{array}$ & $\begin{array}{l}0.047^{*} \\
(0.020)\end{array}$ \\
\hline
\end{tabular}

Note: All regressions control for survey year, survey month, state of residence, age groups, gender, race, marital status, and metropolitan status. The robust standard errors corrected for clustering by state of residence and year of birth are in parentheses.

*Significant coefficient at the 5\% level.

**Significant coefficient at the $1 \%$ level. 
Table 5

Estimates of the Effects of High-school Graduation and Years of Schooling on

Probability of Job Loss

Data source: Current Population Survey (1980-2005), N = 465,081

Instrument for schooling: Compulsory schooling laws and child labour laws

\begin{tabular}{|c|c|c|c|c|c|c|}
\hline & \multicolumn{3}{|c|}{$\begin{array}{l}\text { Endogenous variable is high- } \\
\text { school graduation }\end{array}$} & \multicolumn{3}{|c|}{$\begin{array}{c}\text { Endogenous variable is years of } \\
\text { schooling }\end{array}$} \\
\hline & \multirow{2}{*}{$\begin{array}{l}\text { OLS } \\
(1)\end{array}$} & \multicolumn{2}{|c|}{ IV } & \multirow{2}{*}{$\begin{array}{c}\text { OLS } \\
(4)\end{array}$} & \multicolumn{2}{|c|}{ IV } \\
\hline & & $(2)$ & (3) & & (5) & (6) \\
\hline First stage & & & & & & \\
\hline Compulsory schooling $=9$ & & $\begin{array}{c}0.005 \\
(0.010)\end{array}$ & & & $\begin{array}{r}0.055 \\
(0.085)\end{array}$ & \\
\hline Compulsory schooling $=10$ & & $\begin{array}{l}-0.004 \\
(0.011)\end{array}$ & & & $\begin{array}{c}0.023 \\
(0.091)\end{array}$ & \\
\hline Compulsory schooling $\geq 11$ & & $\begin{array}{c}0.030 \\
(0.016)\end{array}$ & & & $\begin{array}{c}0.147 \\
(0.129)\end{array}$ & \\
\hline Child labour =7 & & $\begin{array}{l}-0.016 \\
(0.010)\end{array}$ & $\begin{array}{l}-0.003 \\
(0.008)\end{array}$ & & $\begin{array}{l}-0.111 \\
(0.088)\end{array}$ & $\begin{array}{l}-0.040 \\
(0.068)\end{array}$ \\
\hline Child labour $=8$ & & $\begin{array}{c}0.009 \\
(0.013)\end{array}$ & $\begin{array}{l}0.020^{*} \\
(0.008)\end{array}$ & & $\begin{array}{c}0.065 \\
(0.112)\end{array}$ & $\begin{array}{c}0.127 \\
(0.070)\end{array}$ \\
\hline Child labour $\geq 9$ & & $\begin{array}{l}0.022^{*} \\
(0.010)\end{array}$ & $\begin{array}{l}0.039 * * \\
(0.008)\end{array}$ & & $\begin{array}{l}0.203 * \\
(0.089)\end{array}$ & $\begin{array}{l}0.293 * * \\
(0.072)\end{array}$ \\
\hline $\begin{array}{l}\text { F-statistic for exclusion of } \\
\text { instruments }\end{array}$ & & 16.23 & 25.78 & & 12.21 & 23.04 \\
\hline$p$-value & & 0.000 & 0.000 & & 0.000 & 0.000 \\
\hline
\end{tabular}

Second stage: dependent variable is an indicator variable for being unemployed at the survey date conditional on being employed one year earlier

High-school graduation $\quad-0.021 * * \quad 0.046 \quad 0.046$

Years of schooling

$(0.001) \quad(0.025) \quad(0.026)$

$$
\begin{array}{ccc}
-0.003^{* *} & 0.006 & 0.005 \\
(0.000) & (0.003) & (0.003)
\end{array}
$$

Note: All regressions control for survey year, survey month, state of residence, age groups, gender, race, marital status, and metropolitan status. The robust standard errors corrected for clustering by state of residence and year of birth are in parentheses.

* Significant coefficient at the 5\% level.

**Significant coefficient at the $1 \%$ level. 
Table 6

Estimates of the Effects of High-school Graduation and Years of Schooling on

Probability of Full-time Re-employment Conditional on Being Unemployed for more than Eight Weeks in the Previous Year

Data source: 1980 Census, $\mathrm{N}=307,171$

Instrument for schooling: Compulsory schooling laws and child labour laws

\begin{tabular}{|c|c|c|c|c|c|c|}
\hline & \multicolumn{3}{|c|}{$\begin{array}{l}\text { Endogenous variable is high- } \\
\text { school graduation }\end{array}$} & \multicolumn{3}{|c|}{$\begin{array}{l}\text { Endogenous variable is years of } \\
\text { schooling }\end{array}$} \\
\hline & \multirow{2}{*}{$\begin{array}{l}\text { OLS } \\
(1)\end{array}$} & \multicolumn{2}{|c|}{ IV } & \multirow{2}{*}{$\begin{array}{l}\text { OLS } \\
(4)\end{array}$} & \multicolumn{2}{|c|}{ IV } \\
\hline & & (2) & (3) & & (5) & (6) \\
\hline First stage & & & & & & \\
\hline Compulsory schooling $=9$ & & $\begin{array}{r}0.038 * * \\
(0.007)\end{array}$ & $\begin{array}{l}0.040 * * \\
(0.007)\end{array}$ & & $\begin{array}{l}0.183 * * \\
(0.061)\end{array}$ & $\begin{array}{l}0.228 * * \\
(0.054)\end{array}$ \\
\hline Compulsory schooling $=10$ & & $\begin{array}{l}0.037 * * \\
(0.009)\end{array}$ & $\begin{array}{l}0.039 * * \\
(0.009)\end{array}$ & & $\begin{array}{l}0.161^{*} \\
(0.070)\end{array}$ & $\begin{array}{l}0.208 * * \\
(0.070)\end{array}$ \\
\hline Compulsory schooling $\geq 11$ & & $\begin{array}{l}0.061^{* *} \\
(0.010)\end{array}$ & $\begin{array}{l}0.063 * * \\
(0.008)\end{array}$ & & $\begin{array}{l}0.298 * * \\
(0.078)\end{array}$ & $\begin{array}{l}0.366 * * \\
(0.062)\end{array}$ \\
\hline Child labour $=7$ & & $\begin{array}{c}-0.022^{*} \\
(0.010)\end{array}$ & & & $\begin{array}{c}-0.148 \\
(0.086)\end{array}$ & \\
\hline Child labour $=8$ & & $\begin{array}{c}0.006 \\
(0.010)\end{array}$ & & & $\begin{array}{c}0.092 \\
(0.088)\end{array}$ & \\
\hline Child labour $\geq 9$ & & $\begin{array}{c}0.002 \\
(0.011)\end{array}$ & & & $\begin{array}{c}0.116 \\
(0.098)\end{array}$ & \\
\hline $\begin{array}{l}\text { F-statistic for exclusion of } \\
\text { instruments }\end{array}$ & & 14.13 & 20.79 & & 11.86 & 11.83 \\
\hline$p$-value & & 0.000 & 0.000 & & 0.000 & 0.000 \\
\hline
\end{tabular}

Second stage: dependent variable is an indicator variable for being full-time re-employed at the survey date conditional on being unemployed for more than eight weeks in the previous year

High-school graduation

$0.112 * * \quad 0.208 * \quad 0.258 * *$

Years of schooling
(0.002)
$(0.087)$
(0.100)

$\begin{array}{ccc}0.025 * * & 0.027 * & 0.043 * \\ (0.000) & (0.012) & (0.018)\end{array}$

Note: All regressions control for state of birth, state of residence, gender, race, and cohort of birth (1916-1925, 1936-1945, etc.). The robust standard errors corrected for clustering by state of birth and year of birth are in parentheses.

*Significant coefficient at the 5\% level.

**Significant coefficient at the $1 \%$ level. 
Table 7

Estimates of the Effects of College Attendance, College Graduation and Years of Schooling on Probability of Full-time Re-employment Conditional on Being Unemployed for more than Eight Weeks in the Previous Year

Data source: 1980 Census, $\mathrm{N}=130,739$

Instrument for schooling: Conscription risk in Vietnam War

\begin{tabular}{|c|c|c|c|c|c|c|}
\hline & \multicolumn{2}{|c|}{$\begin{array}{l}\text { Endogenous } \\
\text { variable is college } \\
\text { attendance }\end{array}$} & \multicolumn{2}{|c|}{$\begin{array}{l}\text { Endogenous } \\
\text { variable is college } \\
\text { graduation }\end{array}$} & \multicolumn{2}{|c|}{$\begin{array}{l}\text { Endogenous } \\
\text { variable is years } \\
\text { of schooling }\end{array}$} \\
\hline & $\begin{array}{c}\text { OLS } \\
(1)\end{array}$ & $\begin{array}{l}\text { IV } \\
(2)\end{array}$ & $\begin{array}{l}\text { OLS } \\
\text { (3) }\end{array}$ & $\begin{array}{l}\text { IV } \\
(4)\end{array}$ & $\begin{array}{l}\text { OLS } \\
(5)\end{array}$ & $\begin{array}{l}\text { IV } \\
\text { (6) }\end{array}$ \\
\hline \multicolumn{7}{|l|}{ First stage } \\
\hline $\begin{array}{l}\text { Conscription risk } \\
\text { in Vietnam War }\end{array}$ & & $\begin{array}{l}1.001 * * \\
(0.169)\end{array}$ & & $\begin{array}{c}0.653 * * \\
(0.108)\end{array}$ & & $\begin{array}{l}4.201^{* *} \\
(0.855)\end{array}$ \\
\hline $\begin{array}{l}\text { F-statistic for } \\
\text { exclusion of } \\
\text { instrument }\end{array}$ & & 35.25 & & 36.71 & & 24.14 \\
\hline$p$-value & & 0.000 & & 0.000 & & 0.000 \\
\hline \multicolumn{7}{|c|}{$\begin{array}{l}\text { Second stage: dependent variable is an indicator variable for being full-time re- } \\
\text { employed at the survey date conditional on being unemployed for more } \\
\text { than eight weeks in the previous year }\end{array}$} \\
\hline College attendance & $\begin{array}{c}0.133 * * \\
(0.003)\end{array}$ & $\begin{array}{l}0.276^{*} \\
(0.130)\end{array}$ & & & & \\
\hline College graduation & & & $\begin{array}{l}0.177 * \\
(0.005)\end{array}$ & $\begin{array}{c}0.423 * \\
(0.195)\end{array}$ & & \\
\hline Years of schooling & & & & & $\begin{array}{c}0.028 * * \\
(0.001)\end{array}$ & $\begin{array}{l}0.066 * \\
(0.031)\end{array}$ \\
\hline
\end{tabular}

Note: All regressions control for state of birth, state of residence, race, cohort-level female college attendance rate, and age groups (21-25, 26-30, 31-35, 36-40, and 41-45). The robust standard errors corrected for clustering by state of birth and year of birth are in parentheses.

* Significant coefficient at the 5\% level.

**Significant coefficient at the $1 \%$ level. 
Table 8

Estimates of the Effects of College Attendance, College Graduation and Years of Schooling on Probability of Job Loss

Data source: 1980 Census, $\mathrm{N}=1,121,629$

Instrument for schooling: Conscription risk in Vietnam War

\begin{tabular}{|c|c|c|c|c|c|c|}
\hline & \multicolumn{2}{|c|}{$\begin{array}{l}\text { Endogenous } \\
\text { variable is college } \\
\text { attendance }\end{array}$} & \multicolumn{2}{|c|}{$\begin{array}{l}\text { Endogenous } \\
\text { variable is college } \\
\text { graduation }\end{array}$} & \multicolumn{2}{|c|}{$\begin{array}{l}\text { Endogenous } \\
\text { variable is years of } \\
\text { schooling }\end{array}$} \\
\hline & $\begin{array}{c}\text { OLS } \\
(1)\end{array}$ & $\begin{array}{l}\text { IV } \\
(2)\end{array}$ & $\begin{array}{l}\text { OLS } \\
\text { (3) }\end{array}$ & $\begin{array}{l}\text { IV } \\
(4)\end{array}$ & $\begin{array}{c}\text { OLS } \\
(5)\end{array}$ & $\begin{array}{l}\text { IV } \\
(6)\end{array}$ \\
\hline \multicolumn{7}{|l|}{ First stage } \\
\hline Conscription risk in & & $0.861 * *$ & & $0.820 * *$ & & $4.697 * *$ \\
\hline Vietnam War & & $(0.114)$ & & $(0.098)$ & & $(0.655)$ \\
\hline $\begin{array}{l}\text { F-statistic for } \\
\text { exclusion of } \\
\text { instrument }\end{array}$ & & 56.94 & & 69.91 & & 51.45 \\
\hline$p$-value & & 0.000 & & 0.000 & & 0.000 \\
\hline \multicolumn{7}{|c|}{$\begin{array}{l}\text { Second stage: dependent variable is an indicator variable for being unemployed at the } \\
\text { survey date conditional on being employed and never being unemployed in } \\
\text { the previous year }\end{array}$} \\
\hline College attendance & $\begin{array}{c}-0.016^{* *} \\
(0.000)\end{array}$ & $\begin{array}{c}-0.105^{* *} \\
(0.015)\end{array}$ & & & & \\
\hline College graduation & & & $\begin{array}{c}-0.015^{* *} \\
(0.000)\end{array}$ & $\begin{array}{c}-0.110 * * \\
(0.014)\end{array}$ & & \\
\hline Years of schooling & & & & & $\begin{array}{c}-0.003^{* *} \\
(0.000)\end{array}$ & $\begin{array}{c}-0.019 * * \\
(0.003)\end{array}$ \\
\hline
\end{tabular}

Note: All regressions control for state of birth, state of residence, race, cohort-level female college attendance rate, and age groups (21-25, 26-30, 31-35, 36-40, and 41-45). The robust standard errors corrected for clustering by state of birth and year of birth are in parentheses.

* Significant coefficient at the 5\% level.

**Significant coefficient at the $1 \%$ level. 


\section{Table A1}

Estimates of the Effects of High-school Graduation and Years of Schooling on Probability of Re-employment with Sample Selection Bias Correction

Data source: Current Population Survey (1980-2005), N = 551,410

Instrument for schooling: Compulsory schooling laws and child labour laws

\begin{tabular}{|c|c|c|c|c|c|c|}
\hline & \multicolumn{3}{|c|}{$\begin{array}{l}\text { Endogenous variable is high- } \\
\text { school graduation }\end{array}$} & \multicolumn{3}{|c|}{$\begin{array}{l}\text { Endogenous variable is years of } \\
\text { schooling }\end{array}$} \\
\hline & \multirow{2}{*}{$\begin{array}{l}\text { Heckit } \\
\text { (1) }\end{array}$} & \multicolumn{2}{|c|}{ Heckit-IV } & \multirow{2}{*}{$\begin{array}{l}\text { Heckit } \\
\text { (4) }\end{array}$} & \multicolumn{2}{|c|}{ Heckit-IV } \\
\hline & & (2) & (3) & & (5) & (6) \\
\hline \multicolumn{7}{|l|}{ First stage } \\
\hline \multirow[t]{2}{*}{ Compulsory schooling $=9$} & & -0.024 & & & -0.091 & \\
\hline & & $(0.016)$ & & & $(0.109)$ & \\
\hline \multirow[t]{2}{*}{ Compulsory schooling $=10$} & & -0.032 & & & -0.145 & \\
\hline & & $(0.018)$ & & & $(0.121)$ & \\
\hline \multirow[t]{2}{*}{ Compulsory schooling $\geq 11$} & & -0.001 & & & -0.043 & \\
\hline & & $(0.022)$ & & & $(0.153)$ & \\
\hline \multirow[t]{2}{*}{ Child labour $=7$} & & 0.008 & 0.003 & & -0.037 & -0.076 \\
\hline & & $(0.019)$ & $(0.017)$ & & $(0.130)$ & $(0.108)$ \\
\hline \multirow[t]{2}{*}{ Child labour $=8$} & & 0.033 & 0.029 & & 0.108 & 0.076 \\
\hline & & $(0.021)$ & $(0.016)$ & & $(0.139)$ & $(0.102)$ \\
\hline \multirow[t]{2}{*}{ Child labour $\geq 9$} & & $0.068 * *$ & $0.063 * *$ & & $0.442 * *$ & $0.398 * *$ \\
\hline & & $(0.019)$ & $(0.016)$ & & $(0.129)$ & $(0.105)$ \\
\hline $\begin{array}{l}\text { F-statistic for exclusion of } \\
\text { instruments }\end{array}$ & & 8.30 & 12.94 & & 9.74 & 15.45 \\
\hline$p$-value & & 0.000 & 0.000 & & 0.000 & 0.000 \\
\hline
\end{tabular}

Second stage: dependent variable is an indicator variable for being re-employed at the survey date conditional on being unemployed one year earlier

High-school graduation $\quad 0.033^{* *} \quad 0.306 * 0.416^{* *}$

$\begin{array}{lcccccc}\text { Years of schooling } & & & & 0.007^{* *} & 0.044^{*} & 0.051^{* *} \\ \text { Inverse Mills Ratio } & 0.290^{* *} & -0.134 & -0.300 & 0.264^{* *} & -0.118 & -0.188 \\ & (0.013) & (0.213) & (0.229) & (0.013) & (0.189) & (0.196)\end{array}$

Note: All regressions control for survey year, survey month, state of residence, age groups, gender, race, marital status, and metropolitan status. First-stage probit model further controls for interaction terms among all covariates except survey month and state of residence dummies. In the first-stage probit model, the control for education is a complete set of dummies for each year of schooling with those with eight years of schooling or less as the base category. For Heckit-IV estimates, the robust standard errors corrected for clustering by state of residence and year of birth are in parentheses.

* Significant coefficient at the $5 \%$ level.

**Significant coefficient at the $1 \%$ level. 